\title{
Partisipasi Warga Dalam Pelestarian Bangunan Dan Struktur Cagar Budaya Di BaluWari
}

\author{
Wahyudin, Murtanti Jani Rahayu, Rizon Pamardhi Utomo \\ Program Studi Perencanaan Wilayah dan Kota, \\ Jurusan Arsitektur, Fakultas Teknik \\ Universitas Sebelas Maret, Surakarta \\ email: niduyhaw.niduyhaw@gmail.com
}

\begin{abstract}
The participation of citizen in the conservation of heritage buildings and structures on Surakarta Baluwarti background by conservation measures are often perceived as a barrier to regional development. It causes people to be hesitant in doing conservation measures. Baluwarti been determined to be of cultural heritage, the citizen in Baluwarti required to actively participate in the conservation of cultural heritage buildings and structures. Conservation of cultural heritage in Baluwarti not limited to protection, but also includes the utilization and development. The problem in this research is how much the participation of citizens in the conservation of cultural heritage buildings and structures in the area of Surakarta Baluwarti. The method used is to conduct field observations, distributing questionnaires, and analyzes the frequency distribution and descriptive analysis. The results of the level of citizen participation Baluwarti in the conservation of buildings and structures in the region. The results of this study indicate that the level of citizen participation at the level Baluwarti being. This result indicates the persistence of participation in conservation, but need to increase the participation of buildings and structures related to the conservation of cultural heritage Baluwarti.
\end{abstract}

Keywords: Building and Structure, Conservation, Cultural Heritage, Participation.

\section{PENDAHULUAN}

Pelestarian cagar budaya merupakan langkah dalam perencanaan kota yang telah diamanatkan dalam Undang - Undang Nomor 11 Tahun 2010 tentang Cagar budaya (UUCB). Melestarikan cagar budaya menjadi hal yang penting bagi perkembangan pembangunan di masa sekarang. Budihardjo (1997:124), mengungkapkan bahwa pelestarian cagar budaya sering dianggap sebagai penghambat pembangunan atau tuntutan nostalgia belaka. Hal ini disebabkan karena kurang tersosialisasinya dan kurang tanggapnya masyarakat terhadap cagar budaya yang mereka miliki.

UUCB menyebutkan pelestarian cagar budaya memiliki asas partisipasi. Asas partisipasi yang dimaksud adalah setiap anggota warga didorong untuk berperan aktif dalam pelestarian cagar budaya.

Kawasan Baluwarti termasuk salah satu cagar budaya yang ada di Kota Surakarta. Baluwarti berasal dari bahasa Portugis baluarte yang berarti benteng, dalam bahasa Jawa artinya tembok istana (Sidharta dan Budihardjo,1989). Sudarwo (2008) menyebutkan Kawasan Baluwarti merupakan cagar budaya yang di dalamnya terdapat komunitas bangsawan beserta tempat tinggalnya.

Secara umum, Kawasan Baluwarti tidak memiliki program khusus terkait pelestarian cagar budaya. Wujud pelestarian yang ada di Kawasan Baluwarti ini perlu dilihat secara mendetail terkait dengan pelindungan, pemanfaatan dan pengembangan cagar budaya yang dilakukan oleh warga. Keberadaan Baluwarti dengan berbagai cagar budayanya menunjukkan kaitan partisipasi warga terhadap pelestarian Cagar Budaya Baluwarti. Wujud partisipasi warga Baluwarti dalam pelestarian cagar budaya, ditunjukan dari pemanfaatan kembali bangunan - bangunan dalem, atau tempat tinggal kerabat keraton yang kurang dimanfaatkan tanpa merusak cagar budaya itu sendiri dan tetap dalam kaidah pelestarian.

Cagar Budaya Baluwarti merupakan cagar budaya dalam bentuk permukiman tradisional. Warga yang bermukim dituntut untuk turut melestarikan cagar budaya yang 
mereka tempati secara maksimal, meliputi bangunan cagar budaya, dan struktur cagar budaya. Partisipasi warga Baluwarti sangat penting guna menunjang keberlangsungan proses konservasi terhadap cagar budaya yang ada. Namun, partispasi yang kurang tepat dapat menyebabkan kerusakan terhadap cagar budaya. Pelestarian cagar budaya yang ada di Baluwarti tidak sebatas pada mempertahankan atau melindungi saja, tetapi juga turut andil dalam pemanfaatan dan pengembangan Baluwarti sebagai kawasan cagar budaya.

Tujuan dari penelitian ini adalah untuk mengetahui tingkat partisipasi warga Baluwarti dalam pelestarian bangunan dan struktur cagar budaya di lingkungannya.

\section{METODE}

\subsection{Ruang Lingkup}

Ruang lingkup wilayah penelitian yaitu Kawasan Baluwarti yang meliputi seluruh Kelurahan Baluwarti. Ruang lingkup bahasan yang digunakan dibatasi oleh aspek pelestarian, yakni pelindungan, pemanfaatan, dan pengembangan terkait cagar budaya. batasan tentang partisipasi mencakup batasan tingkat partisipasi berupa intensitas partisipasi dan luasan partisipasi (Bamberger dan Shams,1989). Sedangkan batasan tentang cagar budaya berfokus pada bangunan dan struktur cagar budaya.

\subsection{Metode Analisis}

Penelitian ini menggunakan pendekatan deduktif. Pendekatan deduktif dilakukan jika penelitian yang dilakukan merupakan penelitian yang berdasarkan teori yang ada digunakan untuk merumuskan variabel guna menjawab rumusan masalah yang ada (Sugiyono, 2009). Analisis yang digunakan adalah analisis deskriptif. Analisis ini mengindentifikasi partisipasi terkait dengan tingkat luasan dan intensitas yang dihubungkan terhadap tindakan pelestarian pelindungan, pemanfaatan, dan pengembangan pada bangunan dan struktur cagar budaya. analisis ini terdiri dari empat tahapan analisis yaitu :

1. Mengidentifikasi partisipasi warga dalam pelindungan Cagar Budaya Baluwarti.
2. Mengidentifikasi partisipasi warga dalam pemanfaatan Cagar Budaya Baluwarti.

3. Mengidentifikasi partisipasi warga dalam pengembangan Cagar Budaya Baluwarti.

4. Menganalisis tingkat partisipasi warga dalam pelestarian Cagar Budaya Baluwarti.

\section{HASIL DAN PEMBAHASAN}

\subsection{Tingkat Partisipasi Pelindungan}

\section{Terhadap Cagar Budaya Baluwarti}

Warga Baluwarti melakukan tindakan pelindungan terhadap bangunan cagar budaya dengan melakukan memperbaiki kerusakan bangunan cagar budaya, namun terhadap struktur cagar budaya warga Baluwarti hanya sebatas mencegah kerusakan terhadap struktur cagar budaya. Pada kenyataannya, terdapat perubahan dan tindakan pelindungan terhadap Cagar Budaya Baluwarti, warga mendirikan bangunan baru di lingkungan bangunan lama, yang menyebabkan hilangnya bangunan-bangunan lama atau elemenelemen penting yang menjadi ciri khas lingkungan. Perkembangan bangunan baru menyebabkan perubahan wujud asli lingkungan tersebut. Lingkungan yang dimaksud antara lain adalah Lingkungan Tamtaman, Lingkungan Carangan, lingkungan Wirengan dan Lingkungan Gambuhan (lokasi lingkungan pada Kawasan Baluwarti, lihat pada lampiran peta).

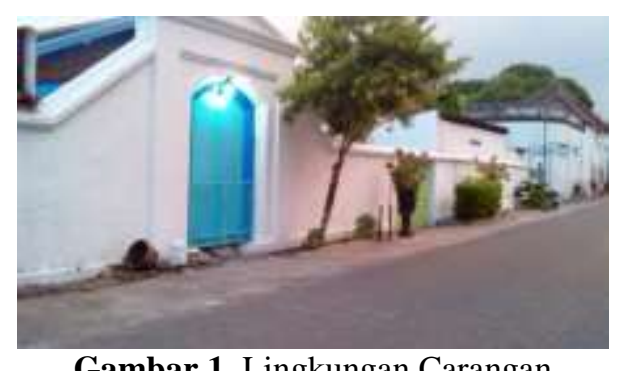

Gambar 1. Lingkungan Carangan Dokumentasi penulis (2014)

Di sisi lain, warga Baluwarti berupaya menjaga bangunan di Baluwarti sehingga keberadaan cagar budaya tersebut masih memiliki kekhasan, yakni Lingkungan Keraton Surakarta, dan beberapa dalem, seperti Dalem Sasana Mulya, Dalem Suryahamijayan, Dalem Purwodiningratan, 
dan Dalem Mlayakusuman (lokasi dalem pada Kawasan Baluwarti, dapat dilihat pada lampiran peta).

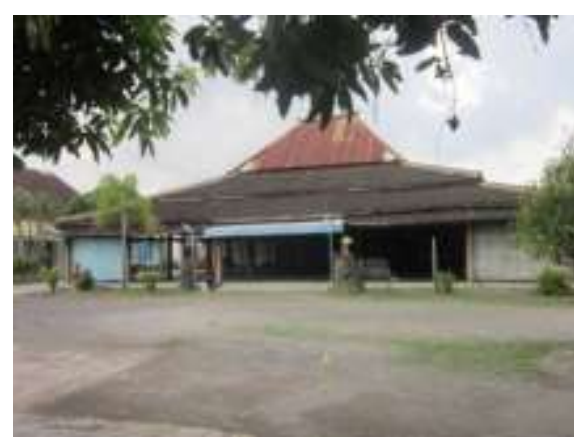

Gambar 2. Dalem Purwodiningratan Dokumentasi penulis (2014)

Jika dikaitkan dengan teori Danisworo (1999) tentang kepentingan pelestarian, maka kepentingan yang menjadi motivasi warga Baluwarti dalam melaksanakan pelindungan cagar budaya adalah motivasi identitas, nilai sejarah, dan nilai arsitektural. Terkait dengan kepentingan identitas, hal ini dapat dilihat dari masih terjaganya Baluwarti sebagai cagar budaya yang memiliki nafas kehidupan, bukan sebagai situs yang mati tanpa kegiatan. Baluwarti juga memiliki kampung kampung dengan identitas yang unik dan menunjukkan keberadaan adanya ikatan sejarah di masa lalu. Peninggalan masa lalu, dalam hal ini Cagar Budaya Baluwarti memiliki peristiwa - peristiwa penting yang dikenang dan dipahami oleh warga Baluwarti sendiri. Tindakan pelindungan bangunan dan struktur cagar budaya yang berada di sekitarnya merupakan tanggung jawab warga Baluwarti selaku warga lokal itu sendiri sebagai pelaku pelestari utama. Sedangkan dalam kepentingan nilai arsitektural, Cagar Budaya Baluwarti dilindungi berdasar keunikan dari gaya bangunan dan kawasannya yang khas akan Arsitektur Tradisional.

Penilaian tingkatan luasan partisipasi dan intensitas partisipasi berdasarkan teori Bamberger dan Shams (1989), warga di Baluwarti mewakilkan partisipasinya kepada kepala keluarga, dan juga ada warga turut serta mengajak anggota keluarga yang lain. Tingkat pastisipasi warga dalam pelindungan Cagar Budaya Baluwarti berada pada tingkat partisipasi tinggi. Pada tingkat ini berarti bahwa peran warga dalam intensitas dan luasan telah menyentuh ke tiap - tiap warga. Hal ini juga menunjukkan, bahwa informasi terhadap pelindungan Cagar Budaya Baluwarti disebarluaskan melalui tiap - tiap kepala keluarga. Intensitas partisipasi warga di Baluwarti selain hanya mendapat informasi, berdiskusi, membuat keputusan, mereka juga melaksanakan pelindungan bangunan cagar budaya. Hal ini menunjukkan bahwa tindakan warga Baluwarti tidak hanya di atas meja saja untuk berunding, namun juga terjun melakukan aksi nyata. Hal ini menandakan tingginya angka intensitas partisipasi warga dalam pelindungan Baluwarti ditunjukkan dengan tindakan yang dilakukan. Partisipasi dengan tingkatan tinggi berarti warga Baluwarti telah melakukan pelindungan terhadap Cagar Budaya Baluwarti dengan memenuhi intensitas partisipasi pada tahap pengambilan keputusan dan mendekati proses pelaksanaan penuh. Sedangkan dalam lingkup luasan, tingkatan partisipasi tinggi ini, telah mencakup semua perwakilan kelompok yang ada di Baluwarti untuk ikut andil dalam pelindungan. Luasan partisipasi terhadap pelindungan Cagar Budaya Baluwarti, melibatkan warga pada tingkat penyertaan perwakilan kelompok. Hal tersebut, dapat diperoleh manfaat yaitu terpilihnya pemimpin warga yang mampu menjadi jembatan bagi warga dalam tindakan pelindungan Cagar Budaya Baluwarti. Selain itu dengan dilibatkannya warga dalam mendapat informasi, berdiskusi, membuat keputusan, kemudian melaksanakan pelindungan bangunan cagar budaya, membuat warga lebih siap dan lebih mengerti terhadap pentingnya pelindungan cagar budaya

\subsection{Tingkat Partisipasi Pemanfaatan Terhadap Cagar Budaya Baluwarti}

Pelaksanaan pemanfaatan Cagar Budaya Baluwarti dikaitkan dengan teori dari Danisworo (1999) oleh warga Baluwarti adalah adanya motivasi kepentingan berupa manfaat ekonomis, manfaat pariwisata, sumber inspirasi dan pendidikan. Manfaat ekonomis ini bisa dilihat dari pemanfaatan 
beberapa dalem di Baluwarti yang difungsikan sebagai fungsi komersial namun masih berada dalam kaidah kaidah pelestarian. Manfaat itu juga terjadi di beberapa kampung yang memanfaatkan potensi sejarahnya manjadi nilai ekonomis. Pemanfaatan cagar budaya sebagai pariwisata juga tidak kalah luput dilakukan oleh warga Baluwarti. Hal ini terjadi secara spontan manakala Keraton Surakarta sebagai atraksi wisata utama di Baluwarti berdampak pada beberapa kawasan di sekitarnya. Kekhasan Cagar Budaya Baluwarti menjadi hal yang menarik untuk dikunjungi yang menyebabkan Cagar Budaya Baluwarti sangat penting untuk dilestarikan karena dapat dipergunakan sebagai area pariwisata. Pemanfaatan dengan kepentingan pendidikan sangat jelas terlihat pada pemanfaatan bangunan sekolah Pamardi Putri milik Yayasan Keraton Surakarta, dan pada pemanfaatan fungsi pendidikan di beberapa bangunan dalem.

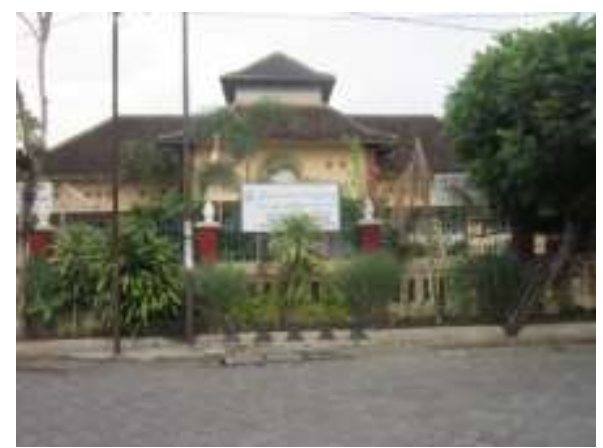

Gambar 3. Pamardi Putri

Dokumentasi penulis (2014)

Motivasi terkait pentinganya pelestarian dalam pendidikan tidak hanya terlihat pada fungsi bangunan saja, namun juga pada bentuk pembelajaran kepada warga Baluwarti tentang sejarah. Cagar Budaya Baluwarti menjadi suatu laboratorium untuk pembelajaran sejarah dan kebudayaan di masa lalu.

Berdasarkan teori Bamberger dan Shams (1989) partisipasi dengan tingkatan sedang berarti warga Baluwarti telah melakukan pemanfaatan terhadap Cagar Budaya Baluwarti dengan memenuhi intensitas partisipasi pada tahap konsultasi. Tahap konsultasi menggambarkan bahwa warga tidak hanya menerima informasi, tetapi juga dapat berkonsultasi pada terkait isu-isu utama dalam beberapa atau semua kegiatan pemanfaatan cagar budaya. Ada kesempatan warga Baluwarti untuk berinteraksi dan memberikan umpan balik yang kemudian dapat diperhitungkan dalam tahap desain dan implementasinya. Dinilai dari tingkatan luasan keterlibatan warga di Baluwarti hanya mewakilkan partisipasinya dari kepala keluarga, meskipun beberapa warga juga turut serta mengajak anggota keluarga yang lain. Selain itu, warga Baluwarti dalam memanfaatkan kawasan masih sebatas memanfaatkan bangunan cagar budaya saja. Tingkatan partisipasi sedang ini, mencakup semua perwakilan kepala rumah tangga yang ada untuk ikut dalam kegiatan pemanfaatan Cagar Budaya Baluwarti. Selain itu juga turut andil nya beberapa perwakilan dalam suatu keluarga baik dari pihak perempuan maupun pihak laki - laki untuk ikut dalam kegiatan pemanfaatan cagar budaya. Tingkat partisipasi pada tindakan pemanfaatan diperoleh tingkat partisipasi sedang. Pada tingkat ini menyimpulakn bahwa warga Baluwarti masih belum dilibatkan secara aktif dalam pemanfaatan terhadap Cagar Budaya Baluwarti, baik terhadap bangunan maupun struktur di sekitarnya. Kurang tingginya partisipasi warga dalam pemanfaatan Cagar Budaya Baluwarti juga disebabkan karena warga memiliki keterbatasan akses terhadap cagar budaya yang ada di sekelilingnya, sehingga warga tersebut tidak mampu memanfaatkan cagar budaya secara maksimal.

Berdasarkan hasil obeservasi bangunanbangunan dalem pangeran dimanfaatkan untuk kepentingan sosial dan pariwisata. Bangunan dalem yang dimaksud adalah dalem Mloyokusuman, dan dalem Purwohamijayan 


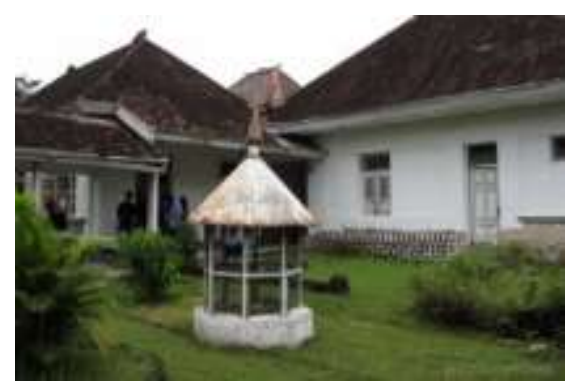

Gambar 4. Dalem Purwohamijayan Dokumentasi penulis (2014)

Berdasarkan analisis partisipasi bahwa intensitas partisipasi pemanfaatan cagar budaya di Baluwarti, menunjukkan warga Baluwarti selain mendapatkan informasi, juga telah sampai pada tahap pelaksanaan tindakan pemanfaatan bangunan.

\subsection{Tingkat Partisipasi Pengembangan Terhadap Cagar Budaya Baluwarti}

Perkembangan Cagar Budaya Baluwarti dirintis sejak masa Paku Buwana II. Pemerintahan selanjutnya, mengembangkan dan menyempurnakan pembangunan fisik yang ada, masa puncak perkembangan yaitu pada masa Paku Buwana X hingga di masa sekarang Keraton Surakarta menjadi kawasan pariwisata.

Selain terjadi perkembangan fisik, juga terjadi perubahan fungsi bangunan dalam Cagar Budaya Baluwarti. Terdapat beberapa bangunan baru dengan bentuk bangunan yang tidak mencerminkan situasi di sekelilingnya (tidak kontekstual), perubahan bentuk muka bangunan dari bentuk aslinya, sehingga kesan historis kawasan Baluwari mulai memudar. Selain itu, semakin berkembangnya jenis kegiatan yang berlangsung di Baluwarti memunculkan fungsi baru yang ditampung oleh kawasan.

Bangunan dalem di Baluwarti yang dahulu merupakan tempat bagi bangsawan, beberapa di antaranya mulai mengalami penambahan komponen yang tidak kontekstual dengan konsep dalem, bahkan Dalem Sindusenen berubah menjadi Pusat Pendidikan Topografi TNI-AD.

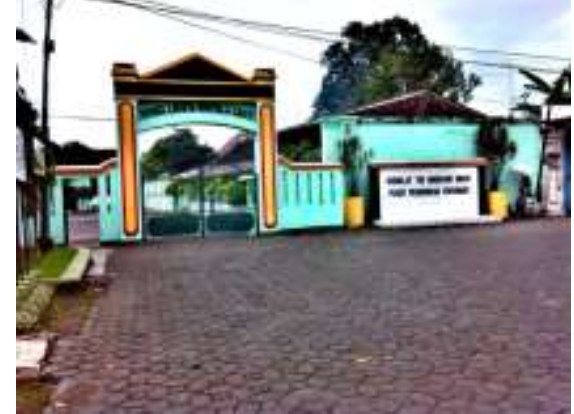

Gambar 5. Dalem Sindusenan

Dokumentasi penulis (2014)

Beberapa rumah tinggal saat ini mulai mengalami pergeseran fungsi menjadi rumah produksi konveksi, kontrakan, rumah kost, maupun disewakan. Banyaknya perubahan yang terjadi di Kawasan Baluwarti dapat menghilangkan proses sejarah yang diwakili oleh visualisasi warisan arsitektur kawasan. Kegiatan pelestarian yang selama ini diterapkan di Baluwarti belum mensinergikan fungsi baru dengan potensi yang dimiliki Cagar Budaya Baluwarti yang dilakukan pada bangunan tertentu sebagai objek tunggal tanpa melihat Kawasan Baluwarti sebagai satu kesatuan. Seperti merenovasi pendhapa, dalem, penghijauan kawasan, pemasangan. Kebijakan yang ada belum mampu mewakili konteks pelestarian, dan perubahan-perubahan kawasan semakin sering terjadi, baik perubahan fungsi maupun perubahan fisik. Namun di sisi lain dalam pengembangan Cagar Budaya Baluwarti, terdapat kepentingan yang sangat vital, yakni kepentingan pengembangan nilai pariwisata, dan pengembangan ekonomi. Cagar Budaya Baluwarti memiliki keunggulan ekonomis, karena letak nya yang strategis di Kota Surakarta, dan beberapa Bangunan serta struktur di sekelilingnya masih menjanjikan untuk atraksi wisata budaya.

Dilihat dari luasan dan intensitas partisipasinya, warga Baluwarti masih kurang berperan dalam pengembangan Cagar Budaya Baluwarti hal ini bahwa tingkat partisipasi warga Baluwarti dalam pengembangan Cagar Budaya Baluwarti adalah sedang. Tingkat ini berarti bahwa baru sebagian kecil warga ikut dilibatkan dalam pengembangan Cagar Budaya 
Baluwarti. Namun peran warga lebih sebagai penerima penjelasan yang dilakukan oleh Pemerintah Kota dan Kelurahan Baluwarti, atau dari pihak Keraton Surakarta selaku pemilik kuasa. Selain itu juga tidak terjadi diskusi terkait tindakan pengembangan apa yang akan dilakukan oleh pemerintah terhadap Cagar Budaya Baluwarti ke depan. Warga hanya mengetahui adanya pengembangan yang sedang berlangsung. Dengan kondisi seperti ini, pengembangan di Cagar Budaya Baluwarti hanya dilakukan oleh kalangan Keraton Surakarta dan Pemerintah Kota Surakarta.

Berdasarkan teori Bamberger dan Shams (1989) partisipasi dengan tingkatan sedang berarti warga Baluwarti telah melakukan pengembangan terhadap Cagar Budaya Baluwarti dengan memenuhi intensitas partisipasi pada tahap konsultasi, tahap konsultasi ini pelaku pengembangan Cagar Budaya Baluwarti tidak hanya menerima informasi, tetapi juga dapat berkonsultasi pada terkait isu-isu utama dalam beberapa atau semua kegiatan pemanfaatan cagar budaya. Ada kesempatan pihak keraton dan warga Baluwarti untuk berinteraksi dan memberikan umpan balik yang kemudian dapat diperhitungkan dalam tahap desain dan implementasinya. Sedangkan dalam lingkup luasan, tingkatan partisipasi sedang ini, telah mencakup semua perwakilan kepala rumah tangga yang ada dan keselurahan pemangku keraton, seperti pengageng keraton untuk ikut dalam kegiatan pengembangan Cagar Budaya Baluwarti. Selain itu juga turut andil dalam kegiatan pengembangan ini sebagian perwakilan warga dalam memberikan masukan kegiatan.

Pengembangan Cagar Budaya Baluwarti dalam lingkup pelestarian memiliki unsur partisipan yakni warga Baluwarti yang menempati Cagar Budaya Baluwarti dan pihak pemerintah dalam hal ini Keraton Surakarta yang mempunyai wewenang dalam penentuan pengembangan kawasan. Unsur warga dalam pengembangan kurang begitu berperan aktif. Meski demikian, peran warga juga sebagai salah satu kunci keberhasilan dalam pengembangan Cagar Budaya Baluwarti. Warga baluwarti mempunyai hak untuk berkonsultasi, menyatakan pendapatnya, dan secara umum supaya kepeduliannya diperlakukan secara sungguh-sungguh yang dalam prosesnya, mereka yang berkepentingan atas suatu tindakan akan terseleksi secara alamiah. Hubungan sinergis antara pemerintah dan pihak keraton, serta warga menjadi bagian penting dalam pelaksanaan pengembangan Cagar Budaya Baluwarti. Pengembangan Cagar Budaya Baluwarti merupakan suatu usaha yang memerlukan kerjasama antara pemerintah, pihak keraton, maupun warga.

\subsection{Tingkat Partisipasi Pelestarian Terhadap Cagar Budaya Baluwarti}

Analisis tingkat partisipasi pelestarian merupakan gabungan dari tingkat partisipasi pelindungan, pemanfaatan, dan pengembangan. Penggabungan ini menggunakan bobot yang dipertimbangkan atas dasar tingkat kepentingan tindakan pelestarian terhadap Cagar Budaya Baluwarti. Pada perhitungan di bab sebelumnya, telah diketahui tingkat partisipasi warga terhadap pelestarian Cagar Budaya Baluwarti berada tingkat sedang. Hal ini menunjukkan masih adanya kerawanan terhadap kerusakan baik terhadap bangunan maupun struktur cagar budaya. Pada dasarnya tindakan pelestarian Cagar Budaya Baluwarti merupakan tanggung jawab Pemerintah dan Keraton Surakarta selaku pemilik, namun Cagar Budaya Baluwarti merupakan cagar budaya yang masih memiliki nafas budaya yang masih ada kegiatan kebudayaan di dalamnya. Warga baik dari kelompok maupun perorangan harus turut berperan serta dalam tindakan pelestarian. Penekanan tindakan pelestarian juga menjadi kewajiban warga Baluwarti yang memiliki atau menguasai bangunan dalem. Jika akses warga umum untuk ikut andil dalam melestarikan tetap dibatasi, maka perlu peran serta yang aktif dari semua elemen warga Baluwarti. Keikutsertaan warga Baluwarti terkait pelestarian dapat disimpulkan bahwa warga masih memiliki peran yang berarti. Adanya warga yang belum ikut andil dalam pelestarian dikarenakan kurangnya sosialisasi dari pihak Pemerintah Surakarta dan pihak 
Keraton Surakarta untuk menggerakkan partisipasi warga. Terlebih lagi warga yang ikut andil dalam pelestarian tidak mendapat keuntungan secara langsung, sehingga sebagian warga menganggap tidak masalah jika tidak ikut dalam partisipasi pelestarian.

\section{KESIMPULAN}

Berdasarkan analisis partisipasi pelestarian terhadap Cagar Budaya Baluwarti, telah diketahui bahwa kondisi tingkat partisipasi pelestarian berada pada tingkatan sedang secara keseluruhan. Hal ini berarti masih perlu peningkatan partisipasi warga di Baluwarti terhadap kawasan tempat tinggalnya terlihat dari adanya perhatian dan tindakan pelindungan, pemanfaatan, dan pengembangan baik pada bangunan maupun struktur cagar budaya. Hal ini terlihat dari tindakan pelindungan yang masih berada pada kegiatan melindungi dan merawat bangunan dan struktur secara parsial. Pada tindakan pengembangan, warga belum sepenuhnya diajak untuk turut serta bersama pemerintah dan pihak keraton.

Masih adanya tindakan partisipasi warga dalam memelihara Cagar Budaya Baluwarti disebabkan latar belakang budaya warga yang memiliki hubungan sejarah dengan benda cagar budaya yang ada di lingkungan tempat tinggal mereka. Umumnya bangunan cagar budaya di Baluwarti merupakan tinggalan leluhur warga Baluwarti. Secara turun-temurun keterkaitan sejarah dan budaya ini terus dibina dan dijaga.

Berdasarkan analisis yang telah dilakukan, dapat disimpulkan bahwa luasan partisipasi terhadap pelestarian di Cagar Budaya Baluwarti masih berada pada partisipasi yang diwakili oleh kepala keluarga dan perwakilan kelompok. Serta diikuti turut andilnya beberapa anggota keluarga. Sedangkan dalam intensitas tindakan, warga yang berada di Baluwarti sudah melakukan tindakan pelestarian secara nyata, dan memberikan umpan balik terhadap pihak keraton, maupun terhadap Pemerintah Kota Surakarta dalam hal pelestarian kawasan.

\section{REFERENSI}

Bamberger, M dan Shams, K. 1989. Community participaton in project management. Asian pacific development centre and economic development institute of the world Bank.

Danisworo dan Martokusumo. 1999. Revitalisasi Kawasan Kota: Sebuah Catatan Dalam Pengembangan dan Pemanfaatan Kawasan Kota

Kementerian Hukum dan Hak Asasi Manusia .2010.UU. No 11 tahun 2010, tentang Cagar budaya.

Sidharta, Budhiarjo Eko, 1989, Konservasi Lingkungan dan Bangunan Kuno Bersejarah Di Surakarta, Gajdah Mada University Press, Yogyakarta

Sudarwo, Agus. 2008. Revitalisasi Kampung Baluwarti Seba gai Kawasan Wisata Budaya. UMS. Surakarta

Sugiyono. 2009. Metode Penelitian Kuantitatif Kualitatif dan $R \& D$. Alfabeta. Bandung. 


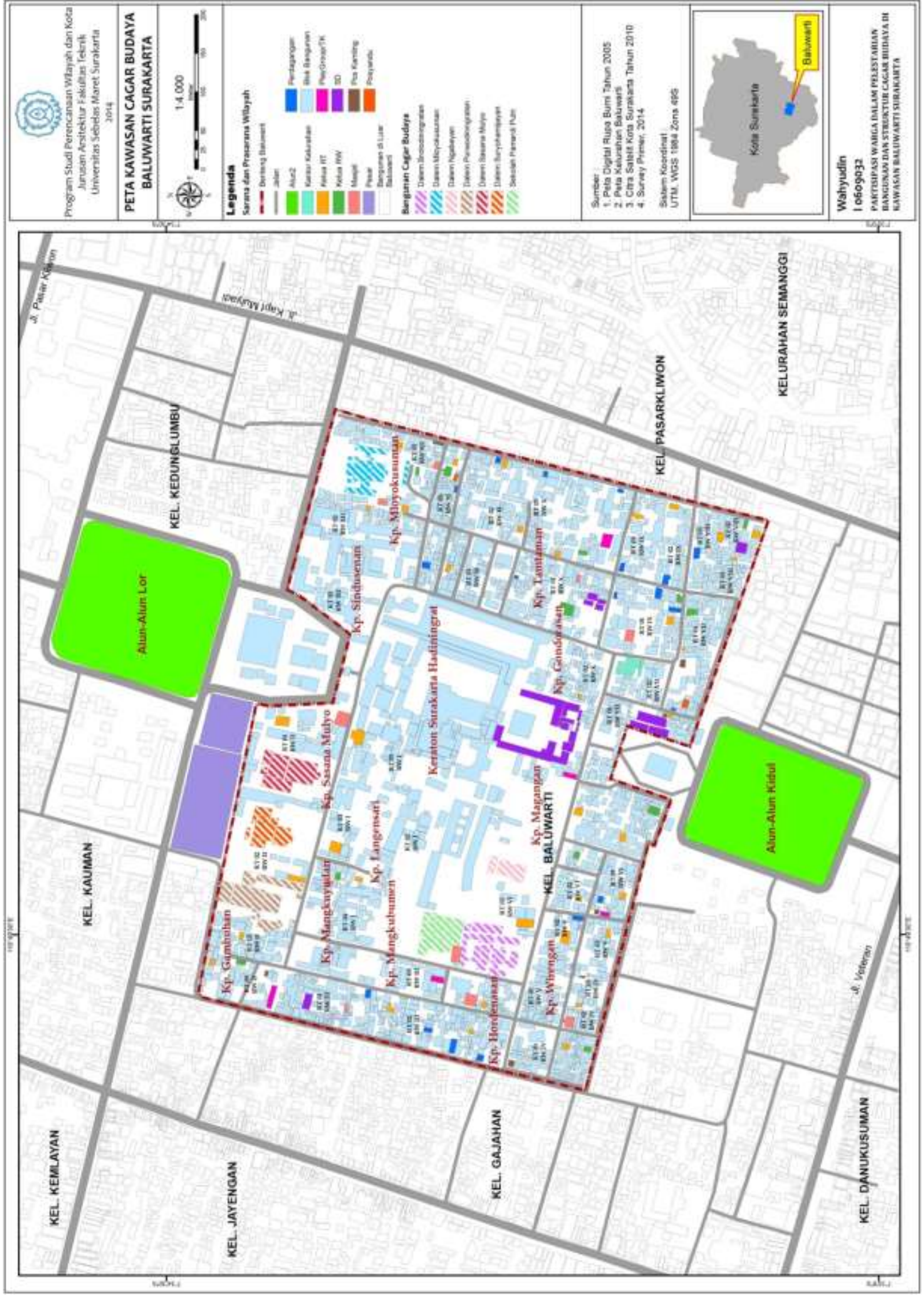